\title{
Genetic characterization of the domestic pig (Sus scrofa domestica) in Cerete-Colombia, using microsatellite markers
}

\author{
Caracterización genética del cerdo doméstico (Sus scrofa \\ domestica) en Cereté - Colombia, usando marcadores \\ microsatélites
}

\author{
Iván Meléndez G, ${ }^{1 *}$ M.Sc, Enrique Pardo $\mathrm{P}^{2}$ Ph.D, Teodora Cavadia M, ${ }^{2}$ M.Sc.
}

\begin{abstract}
${ }^{1}$ Universidad de Pamplona. Faculty of Basic Sciences. Department of Biology. Laboratory of Genetics. Ciudad Universitaria. Pamplona, Colombia. ${ }^{2}$ Universidad de Córdoba. Department of Biology. Genetics Section. Carrera 6 No. 76-103. Monteria. Colombia. *Correspondence: imgelvez@hotmail.com
\end{abstract}

Received: April 2013; Accepted: December 2013.

\begin{abstract}
Objective. The purpose of this study was to characterize a population of domestic pig (Sus scrofa domestica) in Cereté, Córdoba, using 20 microsatellite; calculate heterozygosity per locus and average heterozygosity. Materials and methods. Hair samples were collected from 62 specimens. DNA was extracted by proteinase $\mathrm{K}$ digestion and phenol-chloroform purification. Information from 20 microsatellites was selected out of those recommended for swine biodiversity studies. PCR products were separated by a vertical polyacrylamide gel electrophoresis. The bands were visualized by staining with silver nitrate. Results. All microsatellites used were polymorphic. Between 3 (SW1067) and 15 (IFNG) alleles were detected with an average number of 6.7 and a total de 134 alleles. The average expected and observed heterozygosities were 0.5278 and 0.5479 , respectively. PIC values ranged between 0.1999 and 0.8300 for loci SW1067 and SW911, respectively. Conclusions. Levels of observed and expected heterozygosity found in the present study indicate that the domestic pig (Sus scrofa domestica) in Córdoba Cereté show high degree of genetic variability
\end{abstract}

Key words. Alleles, genetic diversity, heterozygosity (Source: DeCS).

\section{RESUMEN}

Objetivo. El objetivo del presente estudio fue caracterizar una población de cerdo doméstico (Sus scrofa domestica) en Cereté, Córdoba utilizando 20 microsatélites; calcular la heterocigosidad por locus y la heterocigosidad media. Materiales y métodos. Se recolectaron muestras de bulbos de pelo de 62 ejemplares. El ADN se extrajo mediante digestión con proteinasa $\mathrm{K}$ y una purificación con fenol-cloroformo. Se utilizó la información proporcionada por 20 marcadores microsatélites de los recomendados para estudios de biodiversidad porcina. Los productos de PCR se separaron mediante electroforesis vertical en gel de poliacrilamida. Las bandas se visualizaron por tinción con nitrato de plata Resultados. Todos los microsatélites utilizados fueron polimórficos. Se detectaron, entre 3 (SW1067) y 15 (IFNG) alelos, con un número medio de alelos de 6.7 y un total de 134. Las heterocigosidades media esperadas y observadas fueron 0.5278 y 0.5479 respectivamente. Los valores del PIC oscilaron 
entre 0.1999 y 0.8300 para los loci SW1067 y SW911 respectivamente. Conclusiones. Los niveles de heterocigosidad observada y esperada encontrados en el presente estudio, indican que el cerdo doméstico (Sus scrofa domestica) en Cereté Córdoba muestran alto grado de variabilidad genética.

Palabras clave: Alelos, diversidad genética, heterocigosidad (Fuente: DeCS).

\section{INTRODUCTION}

The domestic pig (Sus scrofa domestica) is a four-legged mammal belonging to the group Suinos of the genus Sus (Family Suidae), which is characterized by having four toes ending in the shape of a hoof; the second and third toes serve as support and the first and fourth are not used for support. The fact that it has four hooves places it in the order Artiodactyla.

Its head is long and thick, in common races it is pyramid-shaped. Its skull is solid; in young animals the nose and frontal regions are straight and eventually become concave. The snout is cylindrical in shape with a bulky edge; hairless and smooth; the nostrils are small and its eyes have round pupils.

Domestic pigs in the Americas have their origin in the Iberian pigs brought by Columbus on his second voyage (1). Years later by imposition of Carlos V, the expedition of Rodrigo Bastidas who left La Española and founded Santa Marta in 1525, brought 300 pigs (2). It is possible that the pigs brought by Bastidas were the first that came to Colombia. It was initially raised outdoors with very rudimentary nutrition. It was looked after because of its fertility, meat and fat. Therefore, in each trip of the Spaniards to the American continent the number of pigs increased considerably, until occupying much the Colombian geography. Thus, it became an indispensable factor in the family feeding of natives.

The Department of Cordoba is one of the regions in Colombia with the largest populations of domestic swine (Sus scrofa domestica), made up mostly by the mixture of the creole race called zungo with other races. It seems that the first pigs were introduced into the Department of Cordoba around 1500-1550, at the time of the Conquest and they came from the Spanish breeds known as hairless (3).

The PCR (Polymerase Chain Reaction) is the most used technique for the study of polymorphic markers such as microsatellites or SSRs (Simple Sequence Repeats), formed by DNA segments between two and seven pairs of bases repeated in tandem as neutral markers of high informative value due to their abundance throughout eukaryotic genomes. They display codominant Mendelian inheritance, featuring high polymorphism, their amplification through

\section{INTRODUCCIÓN}

El cerdo doméstico (Sus scrofa domestica) es un mamífero cuadrúpedo perteneciente al grupo Suinos, del genéro Sus (Familia Suidae), que se caracteriza por tener cuatro dedos terminados en forma de pezuña; el segundo y el tercer dedo le sirven de apoyo y el primero y cuarto no los apoya. La posesión de cuatro pezuñas, lo coloca en el orden de los artiodáctilos.

Su cabeza es larga y gruesa, en las razas comunes es de forma piramidal. Su cráneo es sólido; en los animales jóvenes las regiones nasal y frontal son rectas, con el tiempo se hacen cóncavas. El hocico es de forma cilíndrica con un borde abultado; es lampiño y liso; los orificios nasales son pequeños y sus ojos son de pupilas redondas.

Los cerdos domésticos del continente americano tienen su origen en los cerdos ibéricos traídos por Colón en su segundo viaje (1). Años más tarde por imposición de Carlos $\mathrm{V}$, la expedición de Rodrigo Bastidas que partió de la española y fundó a Santa Marta en 1525, trajo 300 cerdos (2). Es posible que los cerdos traídos por Bastidas sean los primeros que llegaron a Colombia. Inicialmente se crió al aire libre con nutrición muy rudimentaria. Era apetecido debido a su fertilidad, carne y grasa. Por eso, en cada viaje de los españoles al continente americano, el número de cerdos aumentó en forma considerable, hasta ocupar gran parte en la geografía de Colombia. Así se convirtió en factor indispensable en la alimentación familiar de los nativos.

El departamento de Córdoba es una de las regiones de Colombia con mayor población de cerdo doméstico (Sus scrofa domestica), formada en su mayoría por la mezcla de la raza criolla denominada zungo con otras razas. Parece que los primeros cerdos fueron introducidos al departamento de Córdoba alrededor de los años 1500-1550, en la época de la Conquista y eran procedentes de las razas españolas conocidas como lampiña (3).

La PCR (Reacción en Cadena de la Polimerasa), es la técnica más utilizada para el estudio de marcadores polimórficos como son los microsatélites o SSRs (Simple Sequence Repeats), formados por segmentos de ADN entre dos y siete pares de bases repetidas en tándem siendo marcadores neutrales de gran valor informativo por su abundancia a lo largo de los genomas eucariotas. Muestran herencia 
PCR as well as the interpretation of the results is simple (4).

This study is justified by the interest in contributing to a wider genetic knowledge of the domestic pig (Sus scrofa domestica) in Cerete, Colombia to reveal the status of genetic variability, a conclusive element in the determination of breeding strategies and genetic conservation programs (4) and the establishment of a database that allows comparing the same with other existing populations.

The objective of this study was to characterize a population of domestic swine (Sus scrofa domestica) in Cerete, Colombia using 20 microsatellite; calculating their heterozygosity per locus, their average heterozygosity and compare this information with that obtained in other populations with the same genetic markers.

\section{MATERIALS AND METHODS}

Study site. The samples were collected in Cerete, Córdoba $\left(08^{\circ} 53^{\prime} 08^{\prime \prime} \mathrm{N}\right.$ and $\left.75^{\circ} 47^{\prime} 48^{\prime \prime} \mathrm{W}\right)$, Colombia.

Sample collection. Hair samples of 62 specimens were collected. The specimens come from family farms, therefore they lack genealogical records.

Experimental procedure. The DNA of each one of the samples was extracted by means of a modification to the protocol described by Sambrook and Russell (5). The DNA was extracted from the hair bulb by digestion of proteins with the enzyme Proteinase $\mathrm{K}$ and phenol-chloroform purification.

The 20 microsatellites used in the study belong to the panel of those recommended by the FAO / ISAG (International Society of Animal Genetics) (6) for swine biodiversity studies. The amplification of the same was carried out using a thermal cycler

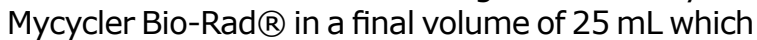
included $10 \mu \mathrm{L}$ of $100 \mu \mathrm{M}$ dNTPs, $2.5 \mu \mathrm{L}$ of a $10 \mathrm{X}$ buffer, $1.0 \mu \mathrm{L}$ of $\mathrm{MgCl}_{2} 25 \mathrm{mM}, 3.0 \mu \mathrm{L}$ of specific primers for each locus of $10 \mathrm{pmol}, 0.3 \mu \mathrm{L}$ of the enzyme Taq DNA polymerase at a concentration of $1 \mathrm{U} / \mu \mathrm{L}, 4.0 \mu \mathrm{L}$ of genomic DNA at a concentration of $50 \mathrm{ng} / \mu \mathrm{L}$ and $4.2 \mu \mathrm{L}$ of sterile bidistilled water.

The PCR reaction consisted of a denaturalization phase at $94^{\circ} \mathrm{C}$ for 30 seconds, followed by 30 denaturation cycles at $94^{\circ} \mathrm{C}$ for 30 seconds, hybridization at $56^{\circ} \mathrm{C}$ for 30 seconds and elongation at $72^{\circ} \mathrm{C}$ for 30 seconds. PCR products were separated by vertical gel electrophoresis of polyacrylamide in a Mini-Protean II Biorad $\mathbb{R}$ chamber. The bands were visualized by staining with silver nitrate (7). mendeliana codominante; presentando un elevado polimorfismo, su amplificación por medio de la PCR así como la interpretación de los resultados es sencilla (4).

La justificación de este estudio es el interés en contribuir a un conocimiento genético más amplio del cerdo doméstico (Sus scrofa domestica) en Cereté, Colombia para evidenciar el estado de la variabilidad genética, un elemento concluyente en la determinación de estrategias de crianza y de programas genéticos de conservación (4) y al establecimiento de una base de datos que permita la comparación de la misma con otras poblaciones actuales.

El objetivo del presente estudio fue caracterizar una población de cerdo doméstico (Sus scrofa domestica) en Cereté, Colombia utilizando 20 microsatélites; calcular sus heterocigosidades por locus, su heterocigosidad media y comparar dicha información con la obtenida en otras poblaciones con los mismos marcadores genéticos.

\section{MATERIALES Y MÉTODOS}

Sitio de estudio. Las muestras fueron recolectadas en Cereté, Córdoba (0853'08" N y 7547'48" W), Colombia.

Recolección de la muestra. Se recolectaron muestras de pelo de 62 ejemplares. Los ejemplares provienen de explotaciones familiares, por lo cual carecen de registros genealógicos.

Procedimiento experimental. De cada una de las muestras se extrajo el ADN mediante una modificación al protocolo descrito por Sambrook y Russell (5). Se procede a la extracción de DNA a partir del bulbo piloso mediante digestión de las proteínas con la enzima Proteinasa $\mathrm{K}$ y una purificación con fenol-cloroformo.

Los 20 microsatelites utilizados para el estudio pertenecen al panel de los recomendados por la FAO/ ISAG (International Society of Animal Genetics) (6) para estudios de biodiversidad porcina. La amplificación de los mismos se efectuó utilizando un termociclador Mycycler Bio-Rad ${ }^{\circledR}$ en un volumen final de $25 \mathrm{~mL}$ que incluyó $10 \mu \mathrm{L}$ de dNTPs $100 \mu \mathrm{M}, 2.5 \mu \mathrm{L}$ de amortiguador 10X, 1.0 $\mu \mathrm{L}$ de $\mathrm{MgCl}_{2} 25 \mathrm{mM}, 3.0 \mu \mathrm{L}$ de cebadores específicos de cada locus de $10 \mathrm{pmol}, 0.3 \mu \mathrm{L}$ de enzima Taq ADN polimerasa a una concentración de $1 \mathrm{U} / \mu \mathrm{L}$, $4.0 \mu \mathrm{L}$ de ADN genómico a una concentración de $50 \mathrm{ng} / \mu \mathrm{L}$ y $4.2 \mu \mathrm{L}$ de agua bidestilada esterilizada.

La reacción de PCR consistió de una fase de desnaturalización a $94^{\circ} \mathrm{C}$ por 30 segundos, seguida 
An allelic ladder was used to determine the size of the alleles and the allelic allocation was made by an adjustment to a linear regression curve developed from the migration distances of fragments of a known size.

Computer software and statistical analysis. The allele frequencies, heterozygosities, the value of $F_{\text {Is }}(8)$, the existence of the Hardy-Weinberg (HW) equilibrium, the allelic richness and the consanguinity coefficient were evaluated using the software GENEPOP v. 4.0.6 (9). Additionally, the Polymorphic Information Content (PIC) of each microsatellite was calculated using the software CERVUS v. 3.0.3 (10).

\section{RESULTS}

All the microsatellites used showed a high degree of polymorphism, evidenced in the average number of alleles per locus, detecting a total of 134 alleles with a range between 3 (SW1067) and 15 (IFNG) per locus (Table 1).

The statistics $F_{I S}$ (Table 2 ) ranged from -0.414 for SW911 to 0.304 for the marker SWR345. Eleven of the 20 markers show a positive sign and 9 have a negative sign. The average $F_{I S}$ found was -0.033 (Table 3).

Table 1. Microsatellites typified, number of alleles detected (NA), repetition and allelic range in domestic pigs in Cerete, Colombia.

\begin{tabular}{|c|c|c|c|}
\hline Marker & NA & Repetition & Allelic Range (pb) \\
\hline SW489 & 7 & $(\mathrm{GT})_{16}$ & $148-181$ \\
\hline SW2519 & 8 & $(C A)_{20}$ & $187-232$ \\
\hline SW780 & 5 & $(\mathrm{GT})_{11}(\mathrm{GA})_{9}$ & $115-170$ \\
\hline SW2083 & 6 & $(\mathrm{GT})_{10}$ & $143-167$ \\
\hline SW2019 & 4 & $(\mathrm{GT})_{14} \mathrm{AT}(\mathrm{GT})_{4}$ & $127-147$ \\
\hline SW2410 & 6 & $(\mathrm{GT})_{15}$ & $103-137$ \\
\hline S0215 & 8 & $(\mathrm{CT})_{18}(\mathrm{CA})_{12}$ & $125-194$ \\
\hline SW72 & 7 & $(\mathrm{GT})_{15}$ & $97-119$ \\
\hline SW911 & 5 & $(C A)_{22}$ & $147-177$ \\
\hline IFNG & 15 & $(\mathrm{GA})_{11}$ & $221-245$ \\
\hline SW1041 & 4 & $(\mathrm{CA})_{9}$ & $93-101$ \\
\hline SWR345 & 5 & $(\mathrm{CA})_{12}$ & $134-160$ \\
\hline TNFB & 12 & $(\mathrm{CTG})_{20}$ & $142-203$ \\
\hline S0385 & 6 & $(C A)_{21}$ & $145-192$ \\
\hline SW787 & 5 & $(\mathrm{CA})_{19}$ & $144-164$ \\
\hline 50090 & 6 & $(C A)_{24}$ & $227-251$ \\
\hline SW1083 & 5 & $(\mathrm{GT})_{15}$ & $108-152$ \\
\hline SW957 & 10 & $(\mathrm{GT})_{28}$ & $112-157$ \\
\hline SW2427 & 7 & $(\mathrm{GT})_{13}$ & $116-146$ \\
\hline SW1067 & 3 & $(\mathrm{CT})_{20}(\mathrm{CA})_{22}$ & $137-175$ \\
\hline
\end{tabular}

de 30 ciclos de desnaturalización a $94^{\circ} \mathrm{C}$ por 30 segundos, hibridización a $56^{\circ} \mathrm{C}$ por 30 segundos y elongación a $72^{\circ} \mathrm{C}$ por 30 segundos. Los productos de PCR se separaron mediante electroforesis vertical en gel de poliacrilamida en una cámara Mini-Protean II Biorad ${ }^{\circledR}$. Las bandas se visualizaron por tinción con nitrato de plata (7).

Para determinar el tamaño de los alelos se utilizó escalera alélica y la asignación alélica se hizo mediante ajuste a una curva de regresión lineal desarrollada a partir de las distancias de migración de los fragmentos de tamaño conocido.

Programas informáticos utilizados y análisis estadístico. Las frecuencias alélicas, las heterocigosidades, el valor de $\mathrm{F}_{\text {Is }}$ (8) la existencia de equilibrio Hardy-Weinberg ( $\mathrm{HW})$, la riqueza alélica y el coeficiente de consanguinidad se evaluaron mediante el programa GENEPOP v. 4.0.6 (9). Adicionalmente, se calculó el Contenido de Información Polimórfica (PIC) de cada microsatélite mediante el programa CERVUS v. 3.0.3 (10).

\section{RESULTADOS}

Todos los microsatélites utilizados mostraron un alto grado de polimorfismo, evidenciado en el

Table 2. Microsatellites typified, heterozygosity expected $(\mathrm{He})$, heterozygosity observed (Ho), polymorphic information content (PIC), probability of equilibrium ( $\mathrm{p}$-val) and inbreeding coefficient $\left(F_{\text {IS }}\right)$ of the domestic pig of Cerete, Colombia.

\begin{tabular}{cccccc}
\hline Marker & He & Ho & PIC & p-val & $\mathbf{F}_{\text {Is }}$ \\
\hline SW489 & 0.4811 & 0.6459 & 0.5222 & 0.5357 NS & -0.292 \\
SW2519 & 0.7836 & 0.8168 & 0.7034 & $0.1362 \mathrm{NS}$ & 0.242 \\
SW780 & 0.5871 & 0.5755 & 0.5156 & $0.0343^{*}$ & 0.199 \\
SW2083 & 0.2564 & 0.3643 & 0.3490 & $0.3454 \mathrm{NS}$ & -0.102 \\
SW2019 & 0.4503 & 0.5544 & 0.5134 & $0.7723 \mathrm{NS}$ & -0.363 \\
SW2410 & 0.7345 & 0.6578 & 0.4567 & $0.5646 \mathrm{NS}$ & 0.027 \\
S0215 & 0.1891 & 0.6566 & 0.7479 & $0.0043^{*}$ & -0.102 \\
SW72 & 0.7507 & 0.6743 & 0.5121 & $0.4341 \mathrm{NS}$ & -0.371 \\
SW911 & 0.4872 & 0.6581 & 0.8300 & $0.742 \mathrm{NS}$ & -0.414 \\
IFNG & 0.6961 & 0.1887 & 0.5173 & $0.3234 \mathrm{NS}$ & 0.045 \\
SW1041 & 0.5789 & 0.4537 & 0.5363 & $0.0427 *$ & -0.296 \\
SWR345 & 0.3459 & 0.3165 & 0.4521 & $0.0965 \mathrm{NS}$ & 0.304 \\
TNFB & 0.6438 & 0.7456 & 0.6812 & $0.4217 \mathrm{NS}$ & 0.066 \\
S0385 & 0.6166 & 0.6781 & 0.5365 & $0.2244 \mathrm{NS}$ & -0.029 \\
SW787 & 0.4332 & 0.3496 & 0.2132 & $0.2072 \mathrm{NS}$ & 0.083 \\
S0090 & 0.6024 & 0.5881 & 0.6176 & $0.0056 *$ & 0.026 \\
SW1083 & 0.4865 & 0.5342 & 0.5587 & $0.4957 \mathrm{NS}$ & 0.098 \\
SW957 & 0.7423 & 0.6914 & 0.5234 & $0.1319 \mathrm{NS}$ & 0.187 \\
SW2427 & 0.4343 & 0.6876 & 0.5158 & $0.7433 \mathrm{NS}$ & -0.214 \\
SW1067 & 0.2564 & 0.1221 & 0.1999 & $0.1189 \mathrm{NS}$ & 0.237 \\
\hline S:Not & $0.96 n+$ & & & &
\end{tabular}

NS: Not significant.

* Markers not in the Hardy-Weinberg equilibrium $(\mathrm{P}<0.05)$ 
Table 3. Number of samples analyzed $(\mathrm{N})$, average number of alleles (NA), allelic richness (RA), average heterozygosity expected $\left(\mathrm{H}_{\mathrm{e}}\right)$, average heterozygosity observed $\left(\mathrm{H}_{0}\right)$, average polymorphic information content (PIC), average inbreeding coefficient $\left(F_{I S}\right)$ for the microsatellites used in the population of domestic pig in Cerete, Colombia.

\begin{tabular}{ccccccc}
\hline $\mathbf{N}$ & NA & RA & $\mathbf{H}_{\mathbf{e}}$ & $\mathbf{H}_{\mathbf{0}}$ & PIC & $\mathbf{F}_{\mathrm{IS}}$ \\
\hline 62 & 6.7 & 6.0 & 0.5278 & 0.5479 & 0.5251 & -0.033 \\
\hline
\end{tabular}

The polymorphic information content (PIC) obtained (Table 2) varied between 0.1999 (SW1067) and 0.8300 (SW911), values that corresponded to markers that showed the lesser and the greater number of alleles. The high degree of polymorphism was also evidenced by the average number of alleles of 6.7 found in the population (Table 3).

Of the microsatellites studied, three were not found to be in the Hardy-Weinberg equilibrium, (SW2083, S0215 and SWR345) which indicates an excess of homozygotes.

\section{DISCUSSION}

Previous studies on the genetic diversity of pigs reported greater and lower average values of alleles per locus as follows: between 5 and 13 alleles; (11, 12) and values between 2 and 3 alleles (13).

After applying the statistics $F_{I S}$ to 20 markers, 11 show a positive sign indicating an excess of homozygotes and 9 show a negative sign. The average $F_{I S}$ of -0.033 indicate a low value of exogamy, but with a slight excess of heterozygotes.

According to Liu et al (14), of the 20 markers analyzed, 15 can be considered as very informative (PIC>0.5) at the time of detecting the genetic variability in the population of domestic pigs in Cerete, Colombia, 3 markers are fairly informative (PIC>0.25) and 2 markers are little informative (PIC $<0.25)$. The average PIC value in this study was lower in comparison with the data previously published in a study conducted with pigs from Portuguese and European breeds (15) and similar to those reported by the studies carried out in Mamellado of Uruguay and native pigs from China $(11,16,17)$.

Of the total number of microsatellites analyzed, seventeen were found in the Hardy-Weinberg equilibrium, so it may indicate that the population is genetically stable (Table 2 ). In principle this could promedio de alelos por locus, detectándose un total de 134 alelos, con un rango comprendido entre 3 (SW1067) y 15 (IFNG) por locus (Tabla 1 ).

El estadístico $F_{I S}$ (Tabla 2) varió entre -0.414 para SW911 y 0.304 para el marcador SWR345. Once de los 20 marcadores presentan signo positivo y 9 presentan signo negativo. El $F_{I S}$ promedio encontrado fue de -0.033 (Tabla 3 ).

El contenido de información polimórfica (PIC) obtenido (Tabla 2) varió entre 0.1999 (SW1067) y 0.8300 (SW911), valores que correspondieron con los marcadores que presentaron el menor y el mayor número de alelos. El alto grado de polimorfismo también fue evidenciado por el número promedio de alelos encontrados en la población de 6.7 (Tabla 3).

De los microsatélites estudiados, tres no se encontraron en equilibrio de Hardy-Weinberg, (SW2083, S0215 y SWR345) lo que indica un exceso de homocigotos.

\section{DISCUSIÓN}

Estudios previos de diversidad genética en cerdos reportan valores promedio mayores y menores de alelos por locus así: entre 5 Y 13 alelos; $(11,12)$ y valores entre 2 Y 3 alelos (13).

Aplicando el estadístico $F_{I S}$ a los 20 marcadores, 11 presentan signo positivo, indicando exceso de homocigotos, y 9 presentan signo negativo. El $F_{I S}$ promedio de -0.033 , indica un valor bajo de exogamia, pero con ligero exceso de heterocigotos.

Según Liu et al (14), de los 20 marcadores analizados, 15 pueden ser considerados muy informativos (PIC>0.5), a la hora de detectar variabilidad genética en la población de cerdo doméstico en Cereté, Colombia, 3 marcadores son medianamente informativos (PIC $>0.25$ ) y 2 marcadores son poco informativos (PIC $<0.25$ ). El valor medio de PIC en el presente estudio, resultó menor en comparación con datos previamente publicados en un estudio realizado con cerdos en razas portuguesas y europeas (15) y similar a los reportados por estudios que se realizaron en Mamellado de Uruguay y en cerdos nativos de China $(11,16,17)$.

Del total de microsatélites analizados, diecisiete se encontraron en equilibrio de Hardy-Weinberg, por lo que puede indicarse que la población es genéticamente estable (Tabla 2). En un principio esto podría mostrar que los apareamientos dentro de la población se produjeron de forma 
show that the mating in the population occurred randomly (in relation to the markers taken into consideration) or that, if there are new animals that have recently joined this population, these come from other populations with the same gene pool of the individuals in the population under analysis (18).

Three loci showed a significant deviation from the $\mathrm{H}-\mathrm{W}$ equilibrium (SW2083, S0215 and SWR345) revealing an excess of homozygotes. The excess of homozygotes in a population may be the result of inbreeding events within the same (19). However, inbreeding equally affects the entire genome so it would be expected that if this phenomenon were to be the most transcendent, all the markers used should show an excess of homozygotes, which is not the case.

Likewise, the existence of a possible genetic structure by subdivision (Wahlund Effect) may also occur. If so, this would mean that there are marked differences between close populations of domestic swine for the markers (SW2083, S0215 and SWR345), but not for the other markers. If these differences for these markers have not been removed it is because the gene flow among nearby populations is limited (aspect not showed by other markers), or that these markers (SW2083, S0215 and SWR345) are linked to genes undergoing selection natural that act differentially at micro or macro-spatial level. Another possibility is the presence of null alleles in such loci (20), an event that can be discarded in this study as it was not found. A founder effect (few reproducers arrived that then multiplied a lot) could have also occurred.

In this study, the average heterozygosity expected of 0.527 and observed of 0.547 (Table 3) shows a high degree of variability, since it is considered as such when values exceeded 0.5 . This value is similar to that reported in previous studies carried out in creole pigs in Uruguay, Cuban creole pigs, the Mexican hairless pigs and Argentinian creole pigs (21-24).

The percentage of heterozygous individuals was over $50 \%$, reaching values of $54,79 \%$ for the average heterozygosity observed and $52.78 \%$ for the average heterozygosity expected. These values are similar to those reported in Denmark and the Netherlands and are exceeded by those reported in China, Brazil and Thailand (25-28).

The parameters mean number of alleles per locus and allelic richness indicate that this population exhibits certain degree of variability.

Since this is the first study where it is attempted to learn the population genetic diversity of Sus scrofa domestic in Cerete, Colombia and there is no prior aleatoria (en lo referente a los marcadores considerados) o que, si hay nuevos animales que se han sumado recientemente a esta población, éstos provienen de otras poblaciones con el mismo acervo genético de los individuos de la población analizada (18).

Tres loci mostraron una desviación significativa con respecto al equilibrio H-W (SW2083, S0215 y SWR345), revelando un exceso de homocigotos. El exceso de homocigotos en una población podría ser el resultado de eventos de endogamia dentro de la misma (19). Sin embargo, la endogamia afecta por igual a todo el genoma por lo que se esperaría que si este fenómeno fuera el más trascendente, todos los marcadores empleados deberían mostrar un exceso de homocigotos, cosa que no ocurre.

Igualmente pudiera ocurrir la existencia de una posible estructura genética por subdivisión, (Efecto Wahlund). De ser así, eso significaría que existen diferencias marcadas entre las poblaciones cercanas de cerdo doméstico para los marcadores (SW2083, S0215 y SWR345), pero no para los otros marcadores. Si esas diferencias para estos marcadores no se han eliminado es porque el flujo génico entre poblaciones cercanas es limitado (aspecto que no muestran los otros marcadores), o que dichos marcadores (SW2083, S0215 y SWR345), están ligados a genes sometidos a selección natural que actúen diferencialmente a nivel micro o macroespacial. Otra posibilidad es la presencia de alelos nulos en dichos loci (20), evento descartable en este estudio por no encontrarse. También pudo haberse dado un efecto fundador (Ilegaron pocos reproductores que se multiplicaron mucho).

En el presente estudio la heterocigosidad media esperada de 0.527 y la observada de 0.547 (Tabla 3), muestran un alto grado de variabilidad, ya que así se considera cuando los valores superan el 0.5. Este valor es similar a los reportados en estudios previos llevados a cabo en cerdos criollos de Uruguay, cerdo Criollo Cubano, el Pelón Mexicano y los criollos argentinos (21-24).

El porcentaje de individuos heterocigotos se comportó por encima del 50\%; alcanzándose valores de $54.79 \%$, para la heterocigosidad media observada y $52.78 \%$ para la heterocigosidad media esperada. Estos valores son similares a los reportados en Dinamarca y Holanda y se ven superados por los reportados en China, Brasil y Tailandia (25-28).

Los parámetros número medio de alelos por locus y riqueza alélica indican que dicha población exhibe cierto grado de variabilidad. 
information allowing to explore the possibility of loss of genetic diversity over time; the possibility of inbreeding processes for this population of the Colombian Caribbean region cannot be ruled out.

The results of this study allow concluding that the microsatellites used in the population of domestic swine (Sus scrofa domestica) in Cerete, Colombia revealed a high degree of polymorphism. In addition, the high percentage of markers with a high PIC would facilitate the implementation and optimization of this technique for other studies on this race such as genealogical research and allocation of individuals to populations. Similarly, the heterozygosity levels observed and expected found in this study indicate that the domestic pig (Sus scrofa domestica) in Cerete, Colombia show a high degree of genetic variability.
Debido a que éste es el primer trabajo en el que se intenta conocer la diversidad genética poblacional de Sus scrofa doméstica en Cereté, Colombia y no se cuenta con información previa que permita explorar la posibilidad de pérdida de diversidad genética en el tiempo; no se puede descartar la posibilidad de procesos endogámicos para esta población de la región del Caribe colombiano.

Los resultados del presente estudio permiten concluir que Los microsatélites utilizados en la población de cerdo doméstico (Sus scrofa domestica) en Cereté-Colombia revelaron un alto grado de polimorfismo. Además, el alto porcentaje de marcadores con un PIC elevado facilitarían la implementación y optimización de esta técnica para otros estudios dentro de la raza como la investigación genealógica y la asignación de individuos a poblaciones. De igual manera los niveles de heterocigosidad observada y esperada encontrados en el presente estudio, indican que el cerdo doméstico (Sus scrofa domestica) en Cereté Colombia muestran alto grado de variabilidad genética.

\section{REFERENCES}

1. Burgos-Paz W, Souza CA, Megens HJ , Ramayo-Caldas $\mathrm{Y}$, Melo $\mathrm{M}$ et al. Porcine colonization of the Americas: a $60 \mathrm{k}$ SNP story. Heredity 2013; 110:321-330.

2. Peña M, Mora C. Historia de Colombia. Bogotá: Editorial Norma; 1977.

3. Cabeza VM. Estudio comparativo de la raza nativa de cerdo Zungo con razas mejoradas. [Tesis de Maestría]. Bogotá Universidad Nacional de Colombia: ICA; 1976.

4. Pimentel L, Tambasco-Talhari D, Pozzi A, Lehmann L, Correia de Almeida L. Genetic characterization of Aberdeen Angus cattle using molecular markers. Genet Mol Biol 2003; 26(2):133-137.

5. Sambrook J, Russell DW. Molecular Cloning: A laboratory manual (3rd ed.). New York: Cold Spring Harbor Laboratory Press; 2001.

6. FAO. Draft guidelines on Molecular Genetic Characterization of Animal Genetic Resources. [Consulta en internet]. ROMA [Accesado marzo de 2013]. 2011. URL Disponible en: http://www.fao.org/docrep/ meeting/022/am652e.pdf
7. Shanlian Q, Jichen C, Si L, Xinjian L. A comparison of silver staining protocols for detecting DNA in polyester-backed polyacrylamide gel. Braz J Microbiol 2012; 43:649-652.

8. Weir BS. Estimating F-Statistics: A Historical View. Philos Sci 2012; 79:637-643.

9. Rousset F. Genepop 007: a complete reimplementation of the genepop software for Windows and Linux. Mol Ecol Resour 2008; 8:103-106.

10. Kalinowski ST, Taper ML, Marshall TC. Revising how the computer program CERVUS accommodates genotyping error increases success in paternity assignment. Mol Ecol 2007; 16:1099-1106.

11. Li SJ, Yang SL, Yang SH, Zhao SH, Fan B, Yu $\mathrm{M}$ et al. Genetic diversity analyses of 10 indigenous Chinese pig populations based on 20 microsatellites. J Anim Sci 2004; 82:368-74. 
12. Megens $\mathrm{HJ}$, Crooijmans R, Cristobal MS, Hui X, Li N, Groenen MM. Biodiversity of pig breeds from China and Europe estimated from pooled DNA samples: differences in microsatellite variation between two areas of domestication. Gen Sel Evol 2008; 40:103-128.

13. Chang $\mathrm{WH}$, Chu HP, Jiang YN, Li SH, Wang $\mathrm{Y}$, Chen $\mathrm{CH}$ et al. Genetic variation and phylogenetics of Lanyu and exotic pig breeds in Taiwan analyzed by nineteen microsatellite markers. J Anim Sci 2009; 87:1-8.

14. Liu K, Muse SV. PowerMarker: integrated analysis environment for genetic marker data. Bioinformatics 2005; 21:2128-2129.

15. Vicente AA, Carolino MI, Sousa MC, Ginja C, Silva FS, Martinez AM et al. Genetic diversity in native and commercial breeds of pigs in Portugal assessed by microsatellites. J Anim Sci 2008; 86:2496-2507.

16. Castro G. Porcicultura urbana y periurbana en ciudades de América Latina y el Caribe. Lima: Ediciones IPES Promoción del Desarrollo Sostenible. 2007.

17. Zhang GX, Wang ZG, Sun FZ, Chen WS, Yang GY, Guo SJ et al. Genetic diversity of microsatellite loci in fifty six Chinese native pig breeds. Yi Chuan Xue Bao 2003; 30(3):225-233.

18. Wang J. On the measurements of genetic differentiation among populations. Genet Res 2012 94:275-289.

19. Allendorf FW, Luikart G. Conservation and the genetics of populations. Massachusetts: Blackwell; 2007.

20. Chapuis MP, Estoup A. Microsatellite null alleles and estimation of population differentiation. Mol Biol Evol 2007; 24(3):621-631.
21. Kelly L, Clop A, Vadell A, Nicolini P, Monteverde S, Amills M, Sánchez A. El cerdo Pampa-Rocha como recurso zoogenético en Uruguay. Veterinaria 2004; 39:155-159.

22. Canul M, Sierra A, Martínez A, Ortiz O, Delgado JV, Vega-Pla J, Pérez G. Caracterización genética del cerdo pelón mexicano mediante marcadores moleculares. Arch Zootec 2005; 54:267-272.

23. Pérez-Pineda E. Caracterización genética del cerdo criollo Cubano utilizando marcadores moleculares. [Tesis doctoral]. España: Universidad de Córdoba; 2005.

24. Revidatti M.A. Caracterización de cerdos criollos del Nordeste Argentino. [Tesis Doctoral]. España: Universidad de Córdoba; 2009.

25. San Cristobal M, Chevalet C, Haley CS, Joosten R, Rattink AP et al. Genetic diversity within and between European pig breeds using microsatellite markers. Anim Genet 2006; 37:189-198.

26. Fang $\mathrm{M}, \mathrm{Hu} \mathrm{X}$, Jin $\mathrm{W}$, Li N, Wu C. Genetic uniqueness of Chinese village pig populations inferred from microsatellite markers. J Anim Sci 2009; 87:3445-3450.

27. Sollero BP, Paiva SR, Faria DA, Guimaraes SE, Castro S, Egito A et al. Genetic diversity of Brazilian pig breeds evidenced by microsatellite markers. Livest Sci 2009; 123:8-15.

28. Shenglin, Y. Genetic diversity of Thai indigenous pigs, wild boars and Chinese Qianbei black pigs based on microsatellite DNA and sequence polymorphism of mitochondrial DNA cytochrome B gene. [Tesis Doctoral]. Nakhon Ratchasima: Suranaree University of Technology, Institute of Agriculture Technology; 2007. 